\title{
Relationship between Teamwork Characteristics and Effectiveness in the Management and Exploitation of Vietnam's Airports
}

\author{
NGUYEN THI BICH CHAM \\ University of Economics HCMC - cham.nguyen64@ gmail.com \\ DUONG TIEN DUNG \\ Vietnam Airlines Corporation - duongtiendung@vietnamairport.vn
}

\begin{abstract}
ARTICLE INFO ABSTRACT
Article history:

Received:

Aug. 222014

Received in revised form

Oct. 012014

Accepted:

Dec. 302014

Keywords:

teamwork, characteristics

The research aims at identifying characteristics of teamwork that affect the teamwork effectiveness in management and exploitation of airports in Vietnam. Applying relevant theories adjusted to fit the specific conditions in Vietnam, the research finds 15 differences in characteristics of teamwork from the original model by Campion et al. (1993). Teamwork effectiveness is determined by two components: team productivity and employee satisfaction. The quantitative research employs proportionate stratified sampling to gather 434 samples and applies two multiple regression models. The results identify 14 characteristics that can help improve the team work effectiveness. The research contributes important evidence of impacts of characteristics of teamwork on teamwork effectiveness in the management and exploitation of airports.
\end{abstract} of teamwork, teamwork effectiveness. 


\section{Introduction}

Today's state-owned enterprises have decisively implemented the restructuring, the focus of which is equitization to promote inner strength, improve management capacity, and employ efficient methods to enhance corporate impacts and value. Particularly, in the domain of management and exploitation of Vietnam's airports, there are various innovative policies aiming to eliminate monopolies inequality in business operations.

To exist in the market without competitions, enterprises only need to concentrate on high productivity and stable quality; thus, the application of MBP (Management by Process) proves absolutely appropriate. As for such method, senior managers only need to bring in a system of coherent policies and regulations, to which participants must fully conform, thereby enabling them to control the entire system. Team members, in this case, might work independently and not necessarily cooperate in teamwork; business efficiency suits requirements notwithstanding.

Participating in the market economy, enterprises must produce what the market requires instead of what they have. Innovation is needed, and MBP, transformed into MBO (Management by Objectives). This procedure calls for great coordination and collaboration among the members, so teamwork is a key factor for success, and studies into the impact of teamwork characteristics on teamwork effectiveness are essential. Since few studies, among many previous ones, address this nexus in Vietnam, another investigation to explore, modify and improve the original research model would substantiate the case.

\section{Theoretical bases}

\subsection{Group \& team, teamwork characteristics and effectiveness}

A group consists of "two or more individuals, interacting and interdependent, who have come together to achieve particular objectives" (Robbins \& Judge, 2008), or group is a collection of at least two entities working interactively and interdependently to achieve a goal identified (Robbins \& Judge, 2012). A work group interacts primarily to share information and to make decisions to help each group member carry out his/her duties.

According to Sisson (2013), "a group is a collection of individuals who coordinate their individual efforts. On the other hand, a team is a group of people who share a 
common purpose and a number of challenging goals. Members of the team are mutually committed to the goals and to each other. This mutual commitment also creates joint accountability which creates a strong bond and a strong motivation to perform." In other words, team members have common commitments and goals, well-defined roles and responsibility, interdependent relations, complementary skills and joint accountability. Team members can gain better performance than individual does.

\section{Table 1}

Similarities and differences between group and team

\begin{tabular}{|c|c|c|}
\hline & WORK GROUP & TEAM \\
\hline \multirow{7}{*}{ 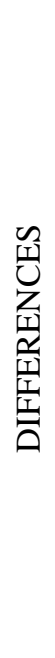 } & Strong, clearly focused leadership & Shared leadership roles \\
\hline & Individual accountability & Individual and mutual accountability \\
\hline & $\begin{array}{l}\text { The group's purpose is the same as the } \\
\text { broader organizational mission }\end{array}$ & $\begin{array}{l}\text { Specific team purpose that the team itself } \\
\text { delivers }\end{array}$ \\
\hline & Individual work-products & Collective work-products \\
\hline & Runs efficient meetings & $\begin{array}{l}\text { Encourages open-ended discussions and } \\
\text { active problem-solving meetings }\end{array}$ \\
\hline & $\begin{array}{l}\text { Measures its effectiveness indirectly by its } \\
\text { influence on others }\end{array}$ & $\begin{array}{l}\text { Measures performance directly by assessing } \\
\text { collective work-products }\end{array}$ \\
\hline & Discusses, decides, and delegates & $\begin{array}{l}\text { Discusses, decides, and does real work } \\
\text { together }\end{array}$ \\
\hline
\end{tabular}

\section{SIMILARITIES}

Consist of at least two members

Directly influence in the long run

Have specified standard rules and values

Perform specific roles

Source: Katzenbach \& Smith (1993)

Based on the study by Katzenbach \& Smith (1993) of work group and team, along with the analysis of concepts, secondary data and research context at Airports Corporation of Vietnam, the authors assume an approach to characteristics of teamwork to be ideally suited for state-owned enterprises at present. Yet, a growing tendency of integration, as well as increasing competitive pressure in the aviation industry, 
necessitates work group activities' having distinct characteristics of teamwork. Thus, the authors have developed the research model based on teamwork characteristics.

Characteristic is a collection of qualities differentiating a person/thing/phenomenon from others. Team characteristics as defined by Campion et al. (1993) involve five criteria constructed by group-working characteristics that affect teamwork effectiveness: (i) job design; (ii) interdependence; (iii) context; (iv) composition; and (v) process.

Rasker et al. (2001) propose a theoretical framework referred to as TNO and determined by such five different factors resulting in team effectiveness as situational, organizational, team, individual, and task factors. Observed items, taken together, are teamwork characteristics mediated by teamwork, which ultimately determines teamwork effectiveness. Robbins and Judge (2008) provide a model of effective teamwork construct based on four main concepts: (i) context; (ii) composition; (iii) job design; and (iv) process. This model can be deemed considerably adequate, aptly summarizing fundamental constituents of effective teamwork.

SAG (2010)'s private training manual indicates several features of teamwork in the exploitation of Vietnam's airports as listed in Table 2.

\section{Table 2}

Teamwork characteristics in relation to teamwork effectiveness

\begin{tabular}{|c|c|c|c|c|}
\hline Independent variable & 1 & 2 & 3 & 4 \\
\hline (1) Job design & $\mathrm{x}$ & $\mathrm{x}$ & $\mathrm{x}$ & $\mathrm{x}$ \\
\hline Self-management & & $\mathrm{x}$ & $\mathrm{x}$ & $\mathrm{x}$ \\
\hline Participation of team members & & & $\mathrm{x}$ & $\mathrm{x}$ \\
\hline Diversity of task assigned & $\mathrm{x}$ & $\mathrm{x}$ & $\mathrm{x}$ & \\
\hline Task significance & $\mathrm{x}$ & $\mathrm{x}$ & $\mathrm{x}$ & $\mathrm{x}$ \\
\hline Task homogeneity & & $\mathrm{x}$ & $\mathrm{x}$ & \\
\hline Task structure & $\mathrm{x}$ & $\mathrm{x}$ & & $\mathrm{x}$ \\
\hline (2) Interdependence & $\mathrm{x}$ & $\mathrm{x}$ & $\mathrm{x}$ & $\mathrm{x}$ \\
\hline - Regarding tasks & $\mathrm{x}$ & & $\mathrm{x}$ & $\mathrm{x}$ \\
\hline - Regarding goals & $\mathrm{x}$ & $\mathrm{x}$ & $\mathrm{x}$ & $\mathrm{x}$ \\
\hline - Regarding feedback and rewards & $\mathrm{x}$ & $\mathrm{x}$ & $\mathrm{x}$ & $\mathrm{x}$ \\
\hline
\end{tabular}


Table 2 (continued)

\begin{tabular}{|c|c|c|c|c|}
\hline Independent variable & 1 & 2 & 3 & 4 \\
\hline (3) Context & $\mathrm{x}$ & $\mathrm{x}$ & $\mathrm{x}$ & $\mathrm{x}$ \\
\hline Training & & & $\mathrm{x}$ & $\mathrm{x}$ \\
\hline \multicolumn{5}{|l|}{ Learning spirits } \\
\hline Managerial support & & & $\mathrm{x}$ & $\mathrm{x}$ \\
\hline Communication/ cooperation between teams & & & $\mathrm{x}$ & $\mathrm{x}$ \\
\hline Sufficient resources & & $\mathrm{x}$ & & \\
\hline Leadership capability and organizational structure & $\mathrm{x}$ & $\mathrm{x}$ & & $\mathrm{x}$ \\
\hline Trustworthy atmosphere & & $\mathrm{x}$ & & $\mathrm{x}$ \\
\hline (4) Team composition & $\mathrm{x}$ & $\mathrm{x}$ & $\mathrm{x}$ & $\mathrm{x}$ \\
\hline Heterogeneity & $\mathrm{x}$ & $\mathrm{x}$ & $\mathrm{x}$ & \\
\hline Flexibility & & $\mathrm{x}$ & $\mathrm{x}$ & $\mathrm{x}$ \\
\hline Relative size & $\mathrm{x}$ & $\mathrm{x}$ & $\mathrm{x}$ & \\
\hline Cordiality & & $\mathrm{x}$ & $\mathrm{x}$ & \\
\hline (5) Process & $\mathrm{x}$ & $\mathrm{x}$ & $\mathrm{x}$ & $\mathrm{x}$ \\
\hline Potency & & $\mathrm{x}$ & $\mathrm{x}$ & $\mathrm{x}$ \\
\hline Social support & $\mathrm{x}$ & & $\mathrm{x}$ & \\
\hline Workload sharing & & $\mathrm{x}$ & $\mathrm{x}$ & $\mathrm{x}$ \\
\hline Communication/ cooperation within the team & $\mathrm{x}$ & & $\mathrm{x}$ & $\mathrm{x}$ \\
\hline Specific goal & $\mathrm{x}$ & $\mathrm{x}$ & & $\mathrm{x}$ \\
\hline Common goal & $\mathrm{x}$ & $\mathrm{x}$ & & \\
\hline Conflicts & & $\mathrm{x}$ & & \\
\hline
\end{tabular}

Note: 1. Rasker et al. (2001); 2. Robbins \& Judge (2008); 3. Campion et al. (1993); 4. SAGS (2010)

Source: Authors' summary

The model introduced by Campion et al. (1993) is applied to our research because of all teamwork characteristics it extracted from previous studies, and its appropriateness to conditions and scope of secondary data analysis in our research. 
Work team effectiveness refers to the level a work team satisfies the expectations of work fulfilment held by partners, managers, clients and others, along with expectations held by team members (Sundstrom, 1998).

Talent Institute (n.d.) suggests that the team effectiveness counts on the three factors: (i) their output is judged to meet or exceed the expectations; (ii) the team should still be able to function effectively upon their completion of all collective task; and (iii) if the team members are pleased with their efforts, if good experiences are acquired, and if time spent away from their normal work has been worth the effort, the team is likely to be effective.

Estimation of team effectiveness based on the team diagnosis model by Nguyen (2013) comprises such factors as service/product quality, productivity, team viability, and employee satisfaction with his job. Salas et al. (1992) assume that three factors used for measuring team effectiveness are: (i) acceptable task output evaluated against original goals agreed upon by the members/organization; (2) team viability; and (3) satisfied members' needs.

In addition, Campion et al. (1993) estimate team effectiveness in terms of three criteria: productivity, satisfaction and manager judgments. Through the presented theories adequate determinants of team effectiveness having been employed in this paper consist of:

Team productivity is the outcome achieved as compared to expectations, team viability, fully tapped resources, efficiency and productiveness.

Employee satisfaction: To evaluate employee satisfaction as a dependent variable, Nguyen (2007) proposes four components namely job challenging the intelligence, fair rewards, favorable working conditions and colleague supports. The approach is adopted to measure the dependent variable in this paper. 


\section{Table 3}

Determinants of team effectiveness

\begin{tabular}{|c|c|c|c|c|c|c|c|}
\hline Dependent var. & $\begin{array}{l}\text { Sundstrom } \\
\text { (1998) }\end{array}$ & $\begin{array}{l}\text { Talent } \\
\text { Institute } \\
\text { (n.d.) }\end{array}$ & $\begin{array}{l}\text { Nguyễn } \\
\text { (2007) }\end{array}$ & $\begin{array}{l}\text { Salas } \\
\text { et al. } \\
(1992)\end{array}$ & $\begin{array}{l}\text { Campion } \\
\text { et al. } \\
\text { (1993) }\end{array}$ & $\begin{array}{c}\text { Robbins } \\
\& \\
\text { Judge } \\
(2008)\end{array}$ & $\begin{array}{l}\text { Secondary } \\
\text { data }\end{array}$ \\
\hline Team productivity & & & $\mathrm{x}$ & & $\mathrm{x}$ & $\mathrm{x}$ & $\mathrm{x}$ \\
\hline $\begin{array}{l}\text { Outcome as } \\
\text { expected }\end{array}$ & $\mathrm{x}$ & $\mathrm{x}$ & $\mathrm{x}$ & $\mathrm{x}$ & $\mathrm{x}$ & $\mathrm{x}$ & $\mathrm{x}$ \\
\hline Team viability & $\mathrm{x}$ & $\mathrm{x}$ & $\mathrm{x}$ & $\mathrm{x}$ & & & \\
\hline $\begin{array}{l}\text { Fully-tapped } \\
\text { resources }\end{array}$ & & & & & $\mathrm{x}$ & $\mathrm{x}$ & $\mathrm{x}$ \\
\hline $\begin{array}{l}\text { Productiveness: } \\
\text { right } \\
\text { implementation of } \\
\text { methods/procedures }\end{array}$ & & & $\mathrm{x}$ & & $\mathrm{x}$ & $\mathrm{x}$ & $\mathrm{x}$ \\
\hline $\begin{array}{l}\text { Efficiency: do } \\
\text { must-do things right }\end{array}$ & & & $\mathrm{x}$ & & $\mathrm{x}$ & $\mathrm{x}$ & $\mathrm{x}$ \\
\hline $\begin{array}{l}\text { Employee } \\
\text { satisfaction }\end{array}$ & & $\mathrm{x}$ & $\mathrm{x}$ & $\mathrm{x}$ & $\mathrm{x}$ & $\mathrm{x}$ & $\mathrm{x}$ \\
\hline $\begin{array}{l}\text { Job challenging the } \\
\text { intelligence }\end{array}$ & & & $\mathrm{x}$ & & $\mathrm{x}$ & $\mathrm{x}$ & $\mathrm{x}$ \\
\hline Fair rewards & & & $\mathrm{x}$ & & $\mathrm{x}$ & $\mathrm{x}$ & $\mathrm{x}$ \\
\hline $\begin{array}{l}\text { Favorable working } \\
\text { conditions }\end{array}$ & & & $\mathrm{x}$ & & $\mathrm{x}$ & $\mathrm{x}$ & $\mathrm{x}$ \\
\hline Colleague support & & & $\mathrm{x}$ & & $\mathrm{x}$ & $\mathrm{x}$ & $\mathrm{x}$ \\
\hline Manager judgment & & & & & $\mathrm{x}$ & $\mathrm{x}$ & \\
\hline
\end{tabular}

Source: Authors' analysis

\subsection{Effects of cultural aspects on teamwork in Vietnam}

The perspective upon teamwork should not conform to any specific stereotype but need to be adopted on the basis of various theories with regard to the effects of cultural 
differences in the context of Vietnam. To rationally apply these theories, authors contemplate cultural effects on teamwork found by Nguyen and Tran (2013) and Truong et al. (1998), which include the following factors:

Power distance: There is a wide power distance in Vietnam, where the role of leadership is not shared.

Individualism/collectivism: Vietnam's teamwork inclines toward collectivism.

Risk aversion: Vietnamese teamwork culture reveals a tendency to evade changes.

Masculinity/femininity: Vietnam's society features femininity; managers strive for consensus, equality, solidarity and high work quality.

Long-/short-term orientation: Vietnamese tend to develop long-term relationships: initially, working hours are spent on building up such relationships and productivity is accentuated afterwards.

\section{Proposed research model}

Among those previous research models, the paper employs the one suggested by Campion et al. (1993) to analyze the relationship between teamwork characteristics and effectiveness.

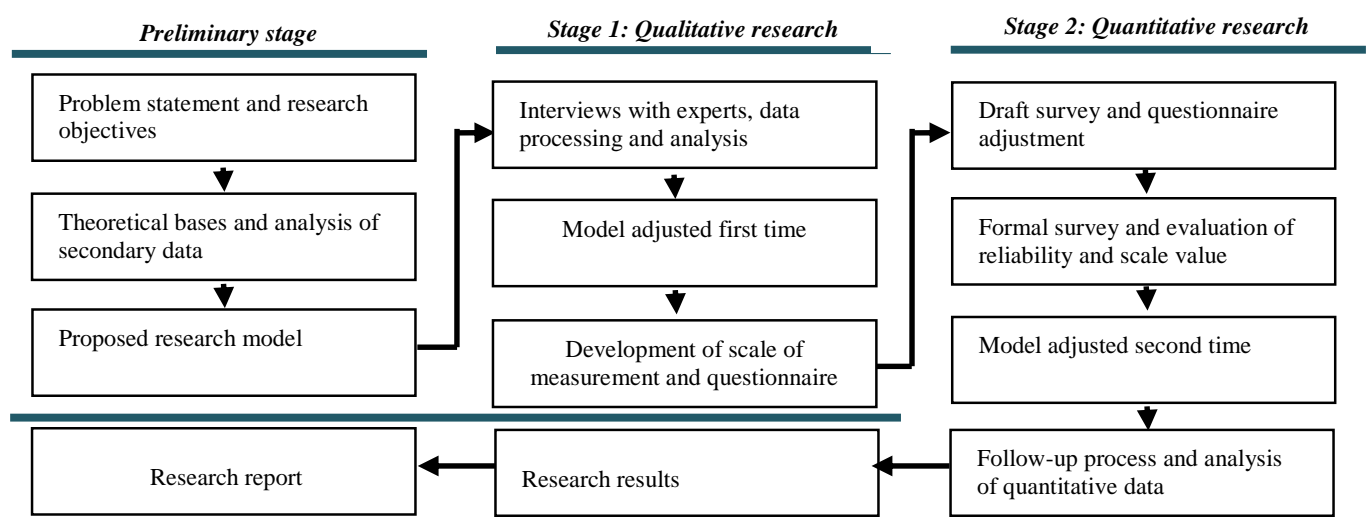

Fig. 1. Holistic Research Process

\section{Methodology}

\subsection{Holistic research process}


The research includes two stages. First, qualitative research is to adjust, modify, and develop the scales of measurement in the original model proposed by Campion et al. (1993). Next, quantitative research is to test the scales and conclude the hypotheses.

\subsection{Qualitative research}

Step 1: Discussion guideline and questionnaires were used for conducting semistructured interviews.

Step 2: Face-to-face interviews were conducted to collect information from eight experts with experience in various departments in Vietnam's airports exploitation. The average duration of each interview was 60 minutes. Unstructured interviews were then held, starting from the fifth expert. The questionnaire was revised three times. Saturation point was reached by the interview of the sixth expert and the whole procedure ceased upon completion of the interview with the eighth expert.

Step 3: Interview contents were documented. Since recording was not allowed by experts, they reaffirmed their brief exchanges in writing. Coding of information is categorized into three groups: confirmed information (accepted or rejected), newly discovered information, and information with adjustment needed. Finally, pieces of information are combined to find consensus about items observed. Opinions are considered consensual once $75 \%$ of agreement is reached (Chu \& Hwang, 2007). 


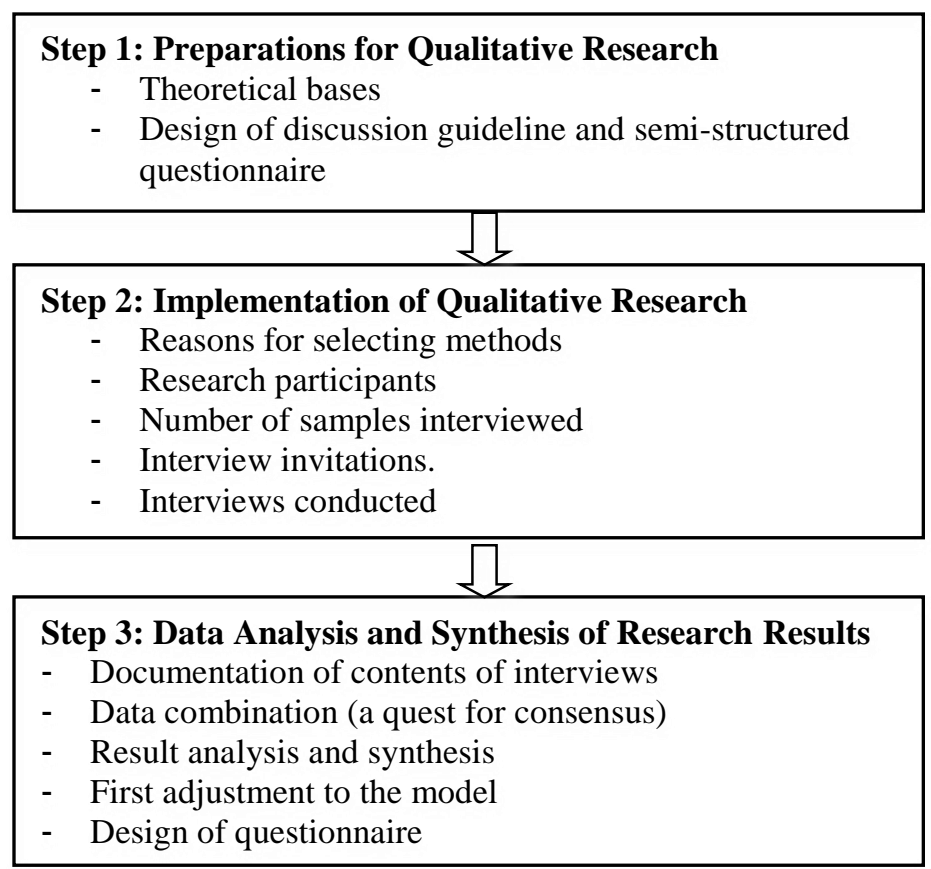

Fig. 2. Qualitative Research Process

\subsection{Design of quantitative research}

A trial survey with 15 respondents was conducted to adjust scales and concepts prior to the formal one. Survey respondents engaging in teamwork were selected according to proportionate stratified sampling method. Expected sample size was 400. The scope of the survey covered functional departments/units of the Airports Corporation of Vietnam (ACV), and its 22 affiliated airports and companies. To achieve the number of valid samples as required, 550 questionnaires and comprehensive instructions were predesigned. Survey duration lasted two weeks in June 2014 and responses were eventually received by post.

Analyzing the research model: This is a multiple variable regression model (MVR) where $\operatorname{COV}(\mathrm{Yi}, \mathrm{Yj})=0$, and $\forall \mathrm{i} \neq \mathrm{j}$ (Steven, 2002). As with this assumption, the research model is actually a set of two multiple linear regression models (MLR).

Processing and analyzing the quantitative data: Reliability of the scales is assessed by Cronbach's Alpha and their validity is tested by EFA, which is followed by regression analysis and hypothesis testing. 


\section{Research results and discussion}

\subsection{Results of qualitative research}

\section{Table 4}

Summary of qualitative research findings

\begin{tabular}{|c|c|c|}
\hline Impact & $\begin{array}{l}\text { Level of } \\
\text { consensus }\end{array}$ & Results of qualitative research \\
\hline Adjustment & $100 \%$ & The term is renamed as "team processing" - abbreviated as QT. \\
\hline $\begin{array}{l}\text { Variable } \\
\text { separation }\end{array}$ & $100 \%$ & $\begin{array}{l}\text { Variables are separated into "Interdependence as for feedback" and } \\
\text { "Interdependence as for rewards" }\end{array}$ \\
\hline Proposal & $100 \%$ & Team members' learning spirit reaches high consensus (100\%). \\
\hline Acceptance & $100 \%$ & New finding: task structure. \\
\hline Acceptance & $100 \%$ & New finding: members' capacity. \\
\hline Acceptance & $100 \%$ & New finding: members' personalities \\
\hline Acceptance & $100 \%$ & New finding: leadership capacity. \\
\hline Acceptance & $75 \%$ & New finding: trustworthy atmosphere. \\
\hline $\begin{array}{l}\text { Reconsiderat } \\
\text { ion } \\
\text { Second time: } \\
\text { elimination }\end{array}$ & $38 \%$ & $\begin{array}{l}\text { New finding: common goal is eliminated during second phone } \\
\text { interviews with experts. }\end{array}$ \\
\hline Acceptance & $75 \%$ & New finding: specific goal. \\
\hline Acceptance & $75 \%$ & New finding: level of conflicts. \\
\hline Elimination & $0 \%$ & Task homogeneity is eliminated. \\
\hline Elimination & $25 \%$ & Team heterogeneity is eliminated. \\
\hline Elimination & $25 \%$ & Relative team size is eliminated. \\
\hline Contraction & $100 \%$ & $\begin{array}{l}\text { Two constructs of dependent variables being contracted are } \\
\text { "productivity" and "employee satisfaction." }\end{array}$ \\
\hline
\end{tabular}

Source: Authors' analysis

The results of the qualitative research (Table 4) allow the adjustments to the model. Regarding independent variables, based on 19 characteristics proposed by Campion et 
al. (1993), the research identifies nine accepted characteristics, rejects three and adjusts the original to 25 characteristics of teamwork. Concerning dependent variables, the qualitative research also reduces three constructs of teamwork effectiveness to two, namely team productivity and employee satisfaction.

\subsection{Results of quantitative research}

The total of 434 qualified samples is presented in Table 5.

\section{Table 5}

Descriptive statistics

\begin{tabular}{|c|c|c|c|}
\hline Criterion & As $\%$ & $\begin{array}{l}\text { Proportionate stratified } \\
\text { sampling }\end{array}$ & As $\%$ \\
\hline Gender: Male & 63.36 & Specialization & \\
\hline Age: $25-35$ years old & 51.61 & Indirect administrative officials & 19.59 \\
\hline Education: University graduate & 53.46 & Firefighter/Security officers & 19.35 \\
\hline Seniority: Over five years & 55.99 & Management of flight operations & 6.68 \\
\hline \multirow[t]{2}{*}{ Position } & & Flight operations officers & \\
\hline & & Ground services agents & 21.43 \\
\hline Direct workers & 78.57 & Drivers, operators & 6.68 \\
\hline $\begin{array}{l}\text { Indirect administration } \\
\text { departments }\end{array}$ & 21.43 & $\begin{array}{l}\text { Maintenance technicians \& } \\
\text { mechanics }\end{array}$ & 19.59 \\
\hline Title & & Manual workers & 6.68 \\
\hline Manager & 22.35 & Clear, tangible questions & 79.46 \\
\hline Specialists/Officials & 77.65 & Respondent's concentration & 95.04 \\
\hline $\begin{array}{l}\text { Samples received from first-level } \\
\text { branches }\end{array}$ & 30.88 & Research content as a concern & 87.82 \\
\hline
\end{tabular}

Source: Calculations from survey data

Assessment of reliability of the scales with Cronbach's Alpha: All components have Cronbach's Alpha $>0.6$ and item-total correlation coefficient $<0.3$ and thereby achieve reliability (Nunnally \& Bernstein, 1994). Such variables as D1 (team self-management) and C5.1, C5.2 (member capacity) are eliminated due to their unsatisfactory item-total correlation and inappropriate theoretical bases, secondary data, results of interviews with 
experts and content values. Although C6 (member personalities), has an unsatisfactory item-total correlation coefficient, it is retained due to being referred to by all experts.

\section{Table 6}

Cronbach's alpha of independent and dependent variables

\begin{tabular}{|c|c|c|c|}
\hline Item & Time & Value & Obs. \\
\hline D. Job design & 2 & 0.692 & 6 \\
\hline I. Interdependence & 1 & 0.651 & 5 \\
\hline C. Composition & 3 & 0.702 & 6 \\
\hline B. Context & 1 & 0.836 & 8 \\
\hline P. Team process & 1 & 0.825 & 8 \\
\hline N. Productivity & 1 & 0.772 & 6 \\
\hline T. Employee satisfaction & 1 & 0.807 & 6 \\
\hline
\end{tabular}

Source: Calculations from survey data

EFA applied to dependent variables: Two observed variables belonging to team productivity and employee satisfaction are eliminated. For the former item, since coefficient $\mathrm{KMO}=0.781(\mathrm{Sig} .=0.000, \alpha=0.05)$ and $\mathrm{TVE}=50.619 \%, \mathrm{~N} 2$ (team viability) is eliminated. For the latter, coefficient $\mathrm{KMO}=0.827$ (Sig. $=0.000, \alpha=0.05$ ) and TVE $=59.126 \%$, T1.2 (challenging task, not too easy but not too difficult) is eliminated. Factor loadings of all observed variables are higher than 0.50 .

EFA applied to independent variables: A series of four EFAs is conducted after the elimination of P7 (level of conflicts), B7 (trustworthy atmosphere), D6 (task structure) and I.1.1 (member interactions for task completion). The fifth EFA with $\mathrm{KMO}=0.885$ (Sig. $=0.000 ; \alpha=0.05)$ satisfies the conditions on appropriate factor analysis; TVE $=$ $59.069 \%$. Rotated component matrix reveals that factor loadings of the observed variables are all higher than 0.50 . The number of extracted components is seven, and two new ones are GK and HT (Table 7). 


\section{Table 7}

Results of EFAs applied to independent variables

\begin{tabular}{lccccccc}
\hline \multicolumn{1}{c}{ Observed variable } & 1 & 2 & 3 & 4 & 5 & 6 & 7 \\
\hline QT (Team process) & P4 & P2 & P1.2 & P3.2 & P3.1 & P6 & P1.1 \\
Factor loading & 0.715 & 0.709 & 0.694 & 0.658 & 0.636 & 0.620 & 0.543 \\
GK (Cohesion of team members) & C4.2 & C4.1 & C6 & D4.1 & D4.2 & I2 & I1.2 \\
Factor loading & 0.713 & 0.642 & 0.630 & 0.584 & 0.559 & 0.528 & 0.501 \\
BC (Scope and resources) & B6.1 & B4 & B3 & B6.2 & & & \\
Factor loading & 0.678 & 0.671 & 0.631 & 0.572 & & & \\
CT (Flexible team composition) & C2.2 & C2.3 & C2.1 & & & & \\
Factor loading & 0.852 & 0.804 & 0.632 & & & & \\
HT (Learning organization) & B1 & B2.1 & B2.2 & & & & \\
Factor loading & 0.720 & 0.699 & 0.647 & & & & \\
TK (Job design) & D3.2 & D3.1 & D2 & & & & \\
Factor loading & 0.785 & 0.785 & 0.593 & & & & \\
PT (Interdependence as for rewards & $\mathrm{I} 4$ & $\mathrm{I} 3$ & & & & & \\
and feedback) & & & & & & & \\
Factor loading & 0.716 & 0.705 & & & & & \\
\hline
\end{tabular}

Source: Analysis from survey data

The present EFA results differ from those of original studies; thus, considerable caution is exercised along the re-evaluation of Cronbach's Alpha applied to the seven components, resulting in achieved reliability of the scales. The model is adjusted, as illustrated in Figure 3, and hypotheses H2a, H4a, H2b, and H4b are included (Table 8).

There exists desirable correlations between the variables, particularly between QT/BC and dependent ones. Concerning Model 1, adjusted R2 $=0.441$ indicates that independent variables explain $44.1 \%$ of changes in team productivity. Similarly, as for Model 2, 39\% of changes in employee satisfaction (TM) is clarified. Another F-test suggests that the regression model features Sig. $=0.000(\alpha=0.05)$ and that the variables sucessfully make clear the variance of dependent variables. Accordingly, the model and the data set are well suited, which may be extended to the whole exploitation of Vietnam airports. 


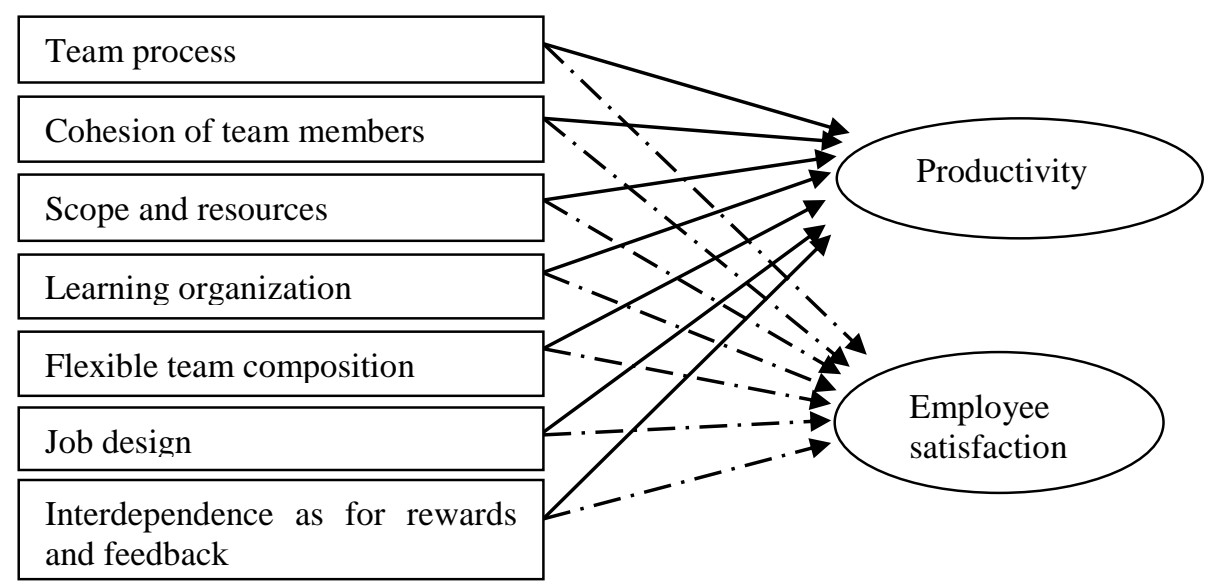

Fig. 3. Second adjustment to the research model

\section{Table 8}

Hypotheses and conclusions

\begin{tabular}{ll}
\hline \multicolumn{1}{c}{ Hypothesis } & Conclusion \\
\hline Model 1 & \\
H1a: QT positively affects NS. & Accepted \\
H2a: GK positively affects NS. & Rejected \\
H3a: BC positively affects NS. & Accepted \\
H4a: HT positively affects NS. & Accepted \\
H5a: CT positively affects NS. & Rejected \\
H6a: TK positively affects NS. & Rejected \\
H7a: PT positively affects NS. & Rejected \\
\hline
\end{tabular}

\section{Model 2}

H1b: QT positively affects TM.

Accepted

H2b: GK positively affects TM.

Rejected

H3b: BC positively affects TM.

Accepted

H4b: HT positively affects TM.

Rejected

H5b: CT positively affects TM.

Rejected

H6b: TK positively affects TM.

Accepted

H7b: PT positively affects TM.

Accepted

Note: Observed data set $\alpha=0.05$

Source: Authors' analysis 
Analysis of regression results from Table 9: Given Model 1 NS, tests for multicollinearity indicate that VIF $<2, t$-tests for QT, BC, and HT produce Sig. $<0.05$, regression coefficients are statistically significant. Particularly, NS is most profoundly impacted by QT $(\beta=0.467)$, followed by BC $(\beta=0.135)$ and HT $(\beta=0.104)$. As for Model 2 TM, no multicollinearity occurs; $t$-test suggests that QT, BC, TK, and PT all come up with statistically significant coefficients, and QT $(\beta=0.365)$ exerts the highest impact on $\mathrm{TM}$, followed by TK $(\beta=0.238), \mathrm{BC}(\beta=0.145)$, and PT $(\beta=0.121)$.

\subsection{Discussion of the results}

The results of qualitative research condition the development of an appropriate research model, demonstrating statistical significance of several adjustments and separation of variables. The present research, in addition, finds that learning spirit of team members is statistically significant. Of the seven characteristics of teamwork newly explored, two are statistically significant, including leadership capacity and specific goal, and it is the elimination of the three characteristics (deemed inappropriate by the experts) that also counts. Compared to the original model, dependent variables are trimmed to two components, namely team productivity and employee satisfaction.

The most noteworthy result of the quantitative research is that EFA results developed seven components from the five given in the original model, and the two new ones are added: learning organization (statistically significant) and cohesion of team members (as yet no ground to conclude). No conclusion about the flexible team composition can be drawn from the results either. The regression results presented in Table 9 demonstrate the impacts of QT and BC on NS and TM, identifying QT's impact as the most significant.

\section{Table 9}

Result of regression analysis

\begin{tabular}{|c|c|c|c|c|c|c|c|}
\hline & & B & $\beta$ & $\mathrm{t}$ & Sig. & $\mathrm{T}$ & VIF \\
\hline Model & 1 & & & & & & \\
\hline Constant & & 1.209 & & 6.502 & 0.000 & & \\
\hline QT & & 0.418 & 0.467 & 9.685 & 0.000 & 0.555 & 1.801 \\
\hline GK & & 0.069 & 0.064 & 1.445 & 0.149 & 0.655 & 1.527 \\
\hline $\mathrm{BC}$ & & 0.109 & 0.135 & 2.725 & 0.007 & 0.524 & 1.909 \\
\hline
\end{tabular}


Table 9 (continued)

\begin{tabular}{|c|c|c|c|c|c|c|c|}
\hline & & B & $\beta$ & $\mathrm{t}$ & Sig. & $\mathrm{T}$ & VIF \\
\hline $\mathrm{CT}$ & & 0.034 & 0.054 & 1.350 & 0.178 & 0.796 & 1.257 \\
\hline HT & & 0.087 & 0.104 & 2.328 & 0.020 & 0.650 & 1.538 \\
\hline TK & & 0.014 & 0.020 & 0.516 & 0.606 & 0.825 & 1.212 \\
\hline PT & & -0.015 & -0.024 & -0.592 & 0.554 & 0.761 & 1.315 \\
\hline Model & 2 & & & & & & \\
\hline Constant & & 0.505 & & 1.898 & 0.058 & & \\
\hline QT & & 0.448 & 0.365 & 7.244 & 0.000 & 0.555 & 1.801 \\
\hline GK & & -0.131 & -0.089 & -1.917 & 0.056 & 0.655 & 1.527 \\
\hline $\mathrm{BC}$ & & 0.160 & 0.145 & 2.788 & 0.006 & 0.524 & 1.909 \\
\hline $\mathrm{CT}$ & & -0.036 & -0.042 & -0.990 & 0.323 & 0.796 & 1.257 \\
\hline HT & & 0.074 & 0.064 & 1.383 & 0.167 & 0.650 & 1.538 \\
\hline TK & & 0.223 & 0.238 & 5.759 & 0.000 & 0.825 & 1.212 \\
\hline PT & & 0.103 & 0.121 & 2.818 & 0.005 & 0.761 & 1.315 \\
\hline
\end{tabular}

Source: Authors' analyses

\section{Conclusions and recommendations on solutions and extended research}

\subsection{Conclusions}

"Sweetening" of teamwork effectiveness may be regarded as a key factor in today's success of any organization. Actually, teamwork performance is not brand new to such a dynamic environment as Vietnam, yet to achieve high efficiency in the context of stateowned enterprises, appropriate characteristics of teamwork should be well researched into. Not only do the managers foreground individual's job performance but it is a prime requirement that their staff is capable of effective mutual interaction and coordination. Findings of the present research indicate 14 accentuated teamwork characteristics, apropos to the basis of solutions offered by administrators in their uplifting teamwork effectiveness.

\subsection{Recommendations on solutions}


Firstly, team process is to be highlighted: the focus would be on issues of communication and collaboration among team members as well as acquisition of necessary information and/or data. Team members need to cultivate mutual support and consideration for each other, not exclusive of social interactions, whereas managers, in their roles, take account of individual's life chances. Mental toughness: team members have certain faith and trust in their work success. Fair workload sharing: managers aim to prevent the matter of buck passing. Reasonable goal-setting: SMART principle is adopted, and team goals are challenging.

Secondly, scope and resources should seriously be contemplated. Communication and collaboration among teams: A mechanism which inclines teams towards effective collaboration, clearly defining tasks and functions as well as team's responsibilities. Management support: This aims at the sharing of accountability, marked by a vision of support and fairness, thereby creating an atmosphere of trust and openness. Leadership capacity: Team leaders are supposed to provide aid for junior members during their confrontations over task hardship. Leaders, in addition, need to take heed of a call for all-out efforts made by team members.

Thirdly, there should be emphasis on learning organization to enhance team productivity: Team training and learning motivation among team members rely heavily on dialogues, discussions, knowledge exchange, going from theory to practice,

Fourthly, concerning employee satisfaction, job design is to be in the limelight: Not just diversification of assigned tasks but active participation of team members is essential. All member's perspectives should be well penetrated and perceived by others and consensus, reached to effectuate the approved task.

Lastly, reward and recognition scheme should be treated with caution as a rise in employee satisfaction probably badly affects team productivity (quantitative research illustrated in Table 8, in fact, demonstrates a negative correlation). Yet, further research is needed to precisely determine such an issue in practice.

\subsection{Main contributions from the research}

Theoretically, the paper inherits and develops Campion et al. (1993)'s model with a view on teamwork performance in accordance with Vietnam's culture and scope of implementation (Table 4 and Subsection 4.3). The research, in addition, employs theoretical basis proposed by Katzenbach \& Smith (1993) to distinguish a group from 
a team. While the concepts 'team' and 'group' are used interchangeably in the majority of Vietnamese books and magazines, it would likely plunge target readers into widespread confusion.

Practically, a shred of valuable evidence has been provided, enabling team leaders to propose solutions that accelerate teamwork effectiveness in the management and exploitation of Vietnam's airports. Managers need to create an experimental platform which allows them to compare the efficacy of teamwork with and without applied research findings in an appropriate period. If actual findings showcase improved teamwork effectiveness, then an extension and general application of the model is highly likely.

\subsection{Limitations and suggestions on extended research}

Given one limitation of the research, its scope of study is based on the assumption that external social situations have no effects on the research model. This is also counted as a constraint not to take into overriding consideration of objective factors affecting the samples studied.

Accordingly, further extended researches are highly recommended to engage characteristics of teamwork performance in various environments. Analysis, on the one hand, involves the effects of these characteristics on teamwork effectiveness with regards to the contrast between state-owned, private and foreign owned enterprises in Vietnam. On the other hand, similar topics can be formulated to compare teamwork characteristics typical of the regional countries, including Vietnam, with countries in other regions

\section{References}

Campion, M., Medsker, G., \& Higgs, A. (1993). Relations between work group characteristics and effectiveness: Implications for designing effective work groups. Personnel Psychology, 46, 823850.

Chu, H.-C., \& Hwang, G.-J. (2007). A Delphi-based approach to developing expert systems with the cooperation of multiple experts. Expert Systems with Applications, 34(4), 2826-2840.

Katzenbach, J., \& Smith, D. (2007). The discipline of teams. Harvard Business Review, 71(2), 111120.

Nguyen, H. L. (2007). Organizational behavior (in Vietnamese). HCMC, Vietnam: Thong Ke Publisher 
Nguyen, H. L. (2013). Course-book of organizational development and change: Team and work diagnosis (in Vietnamese). HCMC, Vietnam: University of Economics HCMC - CEMD

Nguyen, T.T.N. (2013). Finnish and Vietnamese teams: How to improve international teamwork and management practices through cooperation. (Unpublished bachelor's thesis). Jyväskylän ammattikorkeakoulu (JAMK University of Applied Sciences), Finland.

Nunnally, J., \& Burnstein, I. (1994). Psychometric theory, (3 ${ }^{\text {rd }}$ ed.). New York: McGraw-Hill.

Truong, Q., Swierczek, F.W., \& Dang, T.K.C. (1998). Effective leadership in joint ventures in Vietnam: A cross-cultural perspective. Journal of Organizational Change Management, 11(4), 357-372.

Rasker, P., van Vliet, T., van Den Broek, H., \& Essens, P. (2001). Team effectiveness factors: A literature review (TNO Technical Report TM-01-B007), Soesterberg, The Netherlands.

Robbins, S., \& Judge, T. (2008). Essentials of organizational behavior (9th ed.). Upper Saddle River, NJ: Pearson/Prentice Hall.

Robbins, S., \& Judge, T. (2012), Organizational behavior (15 ${ }^{\text {th }}$ ed.). Upper Saddle River, NJ: Prentice Hall.

Saigon Ground Services - SAGS. (2010). A Discourse on teamwork (in Vietnamese). Private training manual. HCMC, Vietnam: Saigon Ground Services Company Ltd.

Salas, E., Dickinson, T., Converse, S., \& Tannenbaum, S. (1992). Toward an understanding of team performance and training. In R. W. Swezey, \& E. Salas (Eds.), Teams: Their training and performance (pp. 3-29), NJ: Ablex.

Sisson, J. (2013). The difference between a group and a team. The Business Journals. Retrieved March 16, 2012 from http://www.bizjournals.com/bizjournals/how-to/growthstrategies/2013/06/the-difference-between-a-group-and-a.html.

Steven, J. (2002). Applied multivariate statistics for the social sciences (4 ${ }^{\text {th }}$ ed.). Mahwah, NJ: Lawrence Erlbaum Associates.

Sundstrom, E. \& Associates. (1998). Supporting work team effectiveness: Best management practices for fostering high performance, San Francisco: Jossey-Bass Publishers.

Talent Institute. (n.d.). The journey to team effectiveness, Richards Bay - South Africa, Dubai - United Arab Emirates. 